\title{
ANALISIS POTENSI PENERAPAN SISTEM RAINWATER HARVESTING PADA APARTEMEN MADISON PARK
}

\author{
Suryadi Suhuyanly', Wati A. Pranoto ${ }^{2}$ \\ ${ }^{1}$ Program Studi Sarjana Teknik Sipil, Universitas Tarumanagara, Jl. Letjen S. Parman No.1 Jakarta \\ Email: s.suhuyanly@gmail.com \\ ${ }^{2}$ Program Studi Sarjana Teknik Sipil, Universitas Tarumanagara, Jl. Letjen S. Parman No.1 Jakarta \\ Email: watip@ft.untar.ac.id
}

\begin{abstract}
ABSTRAK
Indonesia merupakan wilayah dengan curah hujan yang tinggi dan cenderung terdistribusi secara merata sepanjang tahun tanpa ada perbedaan yang mencolok antara musim hujan dan kemarau. Potensi sumber air bersih alami ini, apabila di manfaatkan dalam bentuk sistem Rainwater Harvesting di lokasi Apartemen Madison Park dapat menghemat air bersih per harinya sekitar 27,0497\% pada hari hujan dari kebutuhan air harian menurut perhitungan SNI 03-7065-2005. Sedangkan menurut data tagihan bulanan air, sistem Rainwater Harvesting apabila diterapkan dapat menghemat air hingga 35,766\% pada hari hujan. Biaya air PAM yang dapat dihemat per tahun sebesar Rp 46.700.670, -. Kemudian bak penampung yang dibutuhkan untuk menampung air hujan total sebesar $27 \mathrm{~m}^{3}$.
\end{abstract}

Kata Kunci: rainwater harvesting, penghematan air

\section{PENDAHULUAN}

\section{Latar Belakang}

Air merupakan kebutuhan yang sangat vital bagi kehidupan manusia. Tidak ada manusia yang dapat hidup tanpa air. Di daerah perkotaan seiring pesatnya pembangunan gedung - gedung bertingkat dan perumahaan, kebutuhan air bersih akan selalu meningkat sementara air bersih semakin langka. Indonesia sebagai negara yang beriklim tropis, memiliki curah hujan rata-rata di atas 2 meter per tahun. Artinya kalau semua air hujan yang turun tidak mengalir, tidak meresap dan tidak menguap, maka Indonesia dapat terendam setinggi 2 meter. Jumlah yang terlalu banyak, sehingga malah menimbulkan keluhan. Dengan curah hujan yang demikian tinggi, seharusnya air hujan bisa dimanfaatkan sebagai salah satu alternatif sumber air bersih di Indonesia. Tetapi ketika curah hujan di Indonesia cukup tinggi, masyarakat masih jarang yang memanfaatkannya. Air hujan yang begitu berlimpah, lebih banyak terbuang percuma dibanding untuk dimanfaatkan. Sedangkan saat curah hujan sangat rendah, masyarakat justru kekurangan air. Dibutuhkan manajemen air yang terpadu sehingga dapat tercipta keseimbangan dalam pemanfaatan air. Salah satu cara untuk mewujudkan gagasan tersebut adalah dengan menerapkan konsep panen air hujan (Rainwater Harvesting) yaitu konsep pengumpulan air hujan yang ditampung dalam sebuah reservoir untuk kemudian air yang telah di kumpulan dapat dimanfaatkan sebagai salah satu alternatif sumber air sehingga dapat mengurangi penggunaan air tanah dan bisa digunakan sebagai kegiatan seperti mencuci, mandi, menyiram tanaman, dan toilet. Pada sebuah penelitian di Hotel Novotel Yogyakarta yang dilakukan oleh mahasiswa UGM pada tahun 2014, rata-rata air hujan yang dapat ditampung dalam satu bulan yaitu 478.820 liter dan dalam satu tahun dapat terkumpul sebesar 5.745.809 liter. Pada musim hujan, air hujan pada Hotel Novotel dapat memasok hingga 21\% dari total kebutuhan air bersih dalam satu bulan. Rata-rata konsumsi air yang dapat ditangani oleh air hujan dalam setahun adalah 8,6\%. Oleh sebab itu, penelitian ini dilakukan untuk mengetahui berapa rata-rata air hujan yang dapat ditampung dalam satu hari di Apartemen Madison Park dengan tujuan untuk mengetahui berapa besar penghematan yang dapat diperoleh dengan pemanenan air hujan.

\section{Identifikasi Masalah}

Berdasarkan latar belakang masalah di atas, maka akan dilakukan penelitian untuk pemanenan air hujan (Rainwater Harvesting) di Apartemen Madison Park Jakarta dengan tujuan untuk menghemat sumber air bersih di Apartemen tersebut.

\section{Batasan Masalah}

Batasan masalah dalam penelitian ini yaitu: 
1. Penghitungan curah hujan menggunakan curah hujan rata-rata harian dan curah hujan periode ulang 2, 5, dan 10 tahun.

2. Penelitian dilakukan di Apartemen Madison Park Jakarta

\section{Rumusan Masalah}

Rumusan masalah pada penelitian ini antara lain:

1. Berapa curah hujan di Apartemen Madison Park Jakarta?

2. Berapa volume air yang dapat ditampung?

3. Berapa besar penghematan air apabila sistem RWH ini diterapkan?

\section{Maksud dan Tujuan Penelitian}

Maksud dari penelitian ini adalah untuk mengetahui curah hujan periode ulang 2, 5, dan 10 tahun di Apartemen Madison Park. Dari data yang didapat bisa dicari berapa volume air yang dapat ditampung oleh atap bangunan Apartemen Madison Park. Tujuan dari penelitian ini adalah untuk mengetahui berapa besar potensi penghematan sumber air bersih di Apartemen Madison Park.

\section{DASAR TEORI}

Rainwater Harvesting adalah proses pemanenan air hujan yang ditampung melalui atap sebuah bangunan yang kemudian air hujan tersebut disimpan di dalam sebuah bak atau tangki penampungan (Maryono dan Santoso, E.N., 2006). Konservasi sumber daya air dalam arti penghematan dan penggunaan kembali (reuse) menjadi hal yang sangat penting pada saat ini. Hal ini disebabkan oleh beberapa masalah yang berkaitan dengan ketersediaan air bersih seperti penurunan muka air tanah, kekeringan maupun dampak dari perubahan iklim. Secara ekologis ada empat alasan mengapa memanen air hujan penting untuk konservasi air (Worm, Janette \& Hattum, Tim van, 2006), yaitu:

1. Peningkatan kebutuhan terhadap air berakibat meningkatnya pengambilan air bawah tanah sehingga mengurangi cadangan air bawah tanah. Sistem pemanenan air hujan merupakan alternatif yang bermanfaat.

2. Keberadaan air dari sumber air seperti danau, sungai, dan air bawah tanah sangat fluktuatif. Mengumpulkan dan menyimpan air hujan dapat menjadi solusi saat kualitas air permukaan, seperti air danau atau sungai, menjadi rendah selama musim hujan, sebagaimana sering terjadi di Bangladesh.

3. Sumber air lain biasanya terletak jauh dari rumah atau komunitas pemakai. Mengumpulkan dan menyimpan air di dekat rumah akan meningkatkan akses terhadap persediaan air dan berdampak positif pada kesehatan serta memperkuat rasa kepemilikan pemakai terhadap sumber air alternatif ini.

4. Persediaan air dapat tercemar oleh kegiatan industri mupun limbah kegiatan manusia misalnya masuknya mineral seperti arsenic, garam atau fluoride. Sedangkan kualitas air hujan secara umum relatif baik.

\section{METODOLOGI PENELITIAN}

\section{Alur penelitian}

Penelitian dilaksanakan dengan mengacu pada Gambar 1

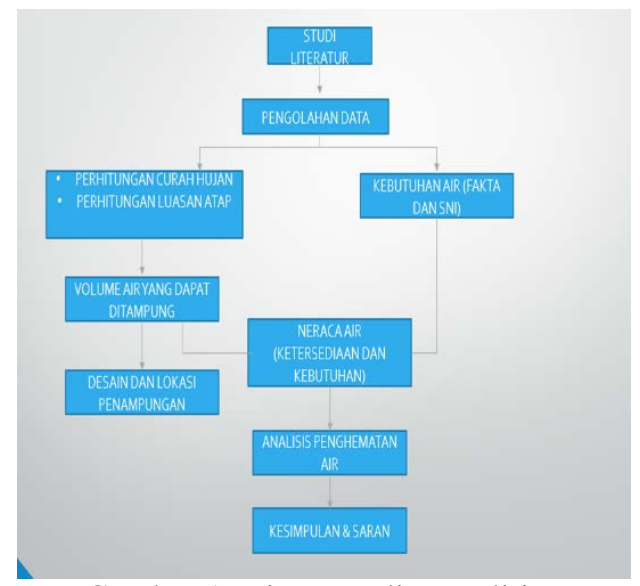

Gambar 1. Diagram alir penelitian 


\section{ANALISIS DAN PEMBAHASAN}

\section{Hasil Analisis Jarak antara Stasiun Hujan Kemayoran dengan Apartemen Madison Park}

Berikut jarak antara Stasiun Meteorologi Kemayoran, Stasiun Klimatologi Tangerang Selatan, Stasiun Meteorologi Maritim Tanjung Priok, dan Stasiun Meteorologi Soekarno Hatta dengan Apartemen Madison Park yang berlokasi di Jalan Letjen S. Parman No.7 seperti pada gambar 2, gambar 3, gambar 4, dan gambar 5

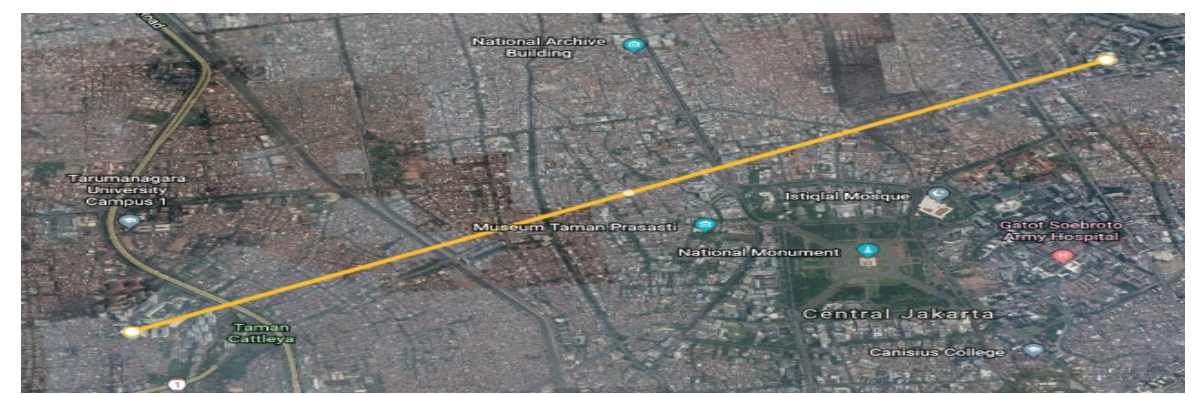

Gambar 2. Jarak antara Apartemen Madison Park dengan Stasiun Meteorologi Kemayoran sejauh 6.396 meter

(Sumber: Google Earth)

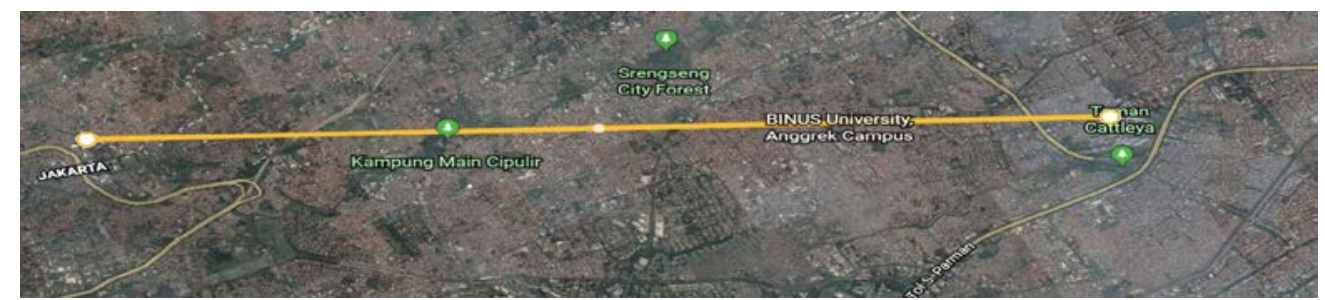

Gambar 3. Jarak antara Apartemen Madison Park dengan Stasiun Klimatologi Tangerang Selatan sejauh 10.009 meter

(Sumber: Google Earth)

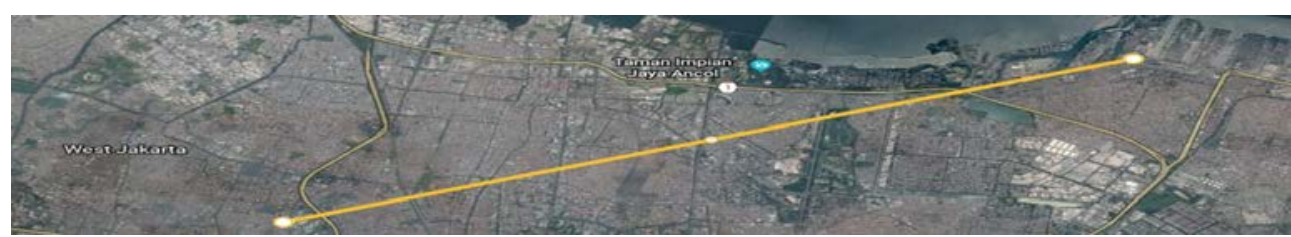

Gambar 4. Jarak antara Apartemen Madison Park dengan Stasiun Meteorologi Maritim Tanjung Priok sejauh 12.866 meter

(Sumber: Google Earth)

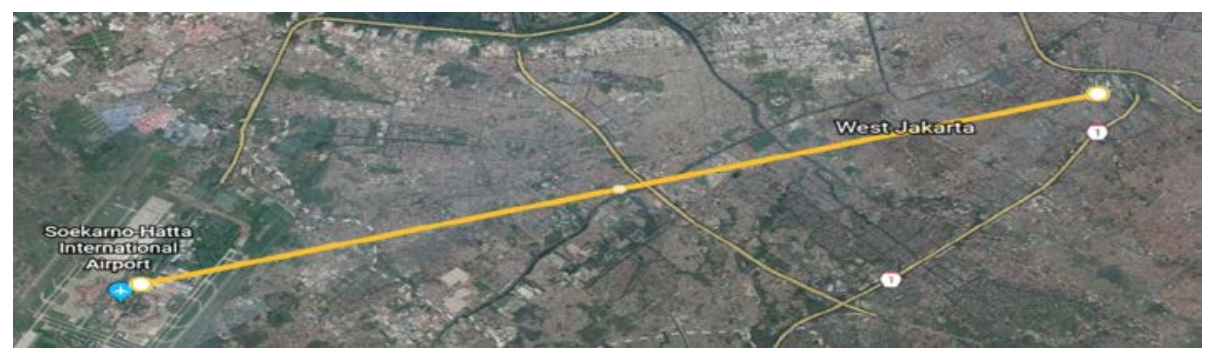

Gambar 5. Jarak antara Apartemen Madison Park dengan Stasiun Meteorologi Soekarno Hatta Sejauh 15,520 meter (Sumber: Google Earth)

Dari hasil survey Google Earth, didapat jarak antara Apartemen Madison Park dengan stasiun hujan antara lain:

- $\quad$ Stasiun Meteorologi Kemayoran

- $\quad$ Stasiun Klimatologi Tangerang Selatan
: 6.396 meter

: 10.009 meter 
- $\quad$ Stasiun Meteorologi Maritim Tanjung Priok

- $\quad$ Stasiun Meteorologi Soekarno Hatta
: 12.866 meter

: 15.520 meter

Maka stasiun hujan dengan jarak terdekat dengan Apartemen Madison Park adalah Stasiun Meteorologi Kemayoran.

\section{Hasil Analisis Curah Hujan Harian Rata-Rata}

Data curah hujan harian rata-rata yang digunakan adalah data dari Stasiun Meteorologi Kemayoran, karena lokasinya berada paling dekat dengan Apartemen Madison Park. Perhitungan seperti pada tabel 1 di bawah.

Tabel 1. Curah Hujan Harian Rata-Rata Stasiun Meteorologi Kemayoran

\begin{tabular}{ccccl}
\hline Tahun & $\begin{array}{c}\text { Jumlah } \\
\text { Curah } \\
\text { Hujan } \\
(\mathrm{mm})\end{array}$ & $\begin{array}{c}\text { Jumlah } \\
\text { Hari Hujan }\end{array}$ & $\begin{array}{c}\text { Curah Hujan Harian Rata-Rata } \\
(\mathrm{mm})\end{array}$ & \multicolumn{1}{c}{$\begin{array}{c}\text { Bulan Hujan } \\
\text { Terbanyak }\end{array}$} \\
\hline $\mathbf{2 0 0 8}$ & 1909,2 & 130 & 14,686 & Februari \\
\hline $\mathbf{2 0 0 9}$ & 1973 & 123 & 16,041 & Januari \\
\hline $\mathbf{2 0 1 0}$ & 2395 & 183 & 13,087 & Januari dan Oktober \\
\hline $\mathbf{2 0 1 1}$ & 1274,1 & 132 & 9,652 & Februari \\
\hline $\mathbf{2 0 1 2}$ & 1488,2 & 122 & 12,198 & $\begin{array}{l}\text { November dan } \\
\text { Desember }\end{array}$ \\
\hline $\mathbf{2 0 1 3}$ & 2528,1 & 169 & 14,959 & Januari dan Desember \\
\hline $\mathbf{2 0 1 4}$ & 2837,1 & 141 & 20,121 & Januari dan Februari \\
\hline $\mathbf{2 0 1 5}$ & 2086,7 & 108 & 19,321 & Januari dan Februari \\
\hline $\mathbf{2 0 1 6}$ & 2711,5 & 181 & 14,981 & Februari \\
\hline $\mathbf{2 0 1 7}$ & 2152,1 & 132 & 16,304 & Februari \\
\hline $\mathbf{2 0 1 8}$ & 1501,6 & 115 & 13,057 & Februari \\
\hline & Total & 1536 & 151,363 & 14,946 \\
\hline Rata-Rata & 139,636 & &
\end{tabular}

Contoh Perhitungan:

$$
\begin{aligned}
\text { Rata }- \text { rata } & =\frac{\sum \text { Curah Hujan Harian Rata }- \text { Rata }}{\text { Jumlah Data }} \\
& =\frac{151,363}{11} \\
& =14,946 \mathrm{~mm}
\end{aligned}
$$

\section{Hasil Perhitungan dengan Metode Gumbel}

Hasil perhitungan curah hujan rencana dengan menggunakan Metode Gumbel dapat diliat pada tabel 2 dibawah ini.

Tabel 2. Perhitungan Metode Gumbel untuk Stasiun Meteorologi Kemayoran

\begin{tabular}{ccccc}
\hline Tahun & $\begin{array}{c}\text { Curah Hujan } \\
\text { Maksimum }(\mathrm{Xi})\end{array}$ & $(\mathrm{Xi}-\mathrm{X})^{2}$ & ${ }^{2}$ & \\
& & & \\
\hline $\mathbf{2 0 0 8}$ & 192,7 & 1744,960 & 72891,773 & 3044888,209 \\
\hline $\mathbf{2 0 0 9}$ & 122,5 & 808,109 & $-22972,356$ & 653041,4381 \\
\hline $\mathbf{2 0 1 0}$ & 93 & 3355,568 & $-194378,949$ & 11259842,25 \\
\hline $\mathbf{2 0 1 1}$ & 119,2 & 1006,619 & $-31937,299$ & 1013283,399 \\
\hline $\mathbf{2 0 1 2}$ & 105,2 & 2090,983 & $-95614,966$ & 4372211,598 \\
\hline $\mathbf{2 0 1 3}$ & 193,4 & 1803,932 & 76617,939 & 3254172,911 \\
\hline
\end{tabular}




\begin{tabular}{rcccc}
\hline $\mathbf{2 0 1 4}$ & 147,9 & 9,164 & $-27,743$ & 83,98578311 \\
\hline $\mathbf{2 0 1 5}$ & 277,5 & 16020,655 & 2027778,068 & 256661401,8 \\
\hline $\mathbf{2 0 1 6}$ & 124,5 & 698,400 & $-18456,825$ & 487763,5453 \\
\hline $\mathbf{2 0 1 7}$ & 179,7 & 827,869 & 23820,0747 & 685368,5325 \\
\hline $\mathbf{2 0 1 8}$ & 104,6 & 2146,216 & $-99428,338$ & 4606243,681 \\
\hline Jumlah & $\mathbf{1 6 6 0 , 2}$ & $\mathbf{3 0 5 1 2 , 4 8 1}$ & $\mathbf{1 7 3 8 2 9 1 , 3 7 6}$ & $\mathbf{2 8 6 0 3 8 3 0 1 , 3}$ \\
\hline Rata-rata & $\mathbf{1 5 0 , 9 2 7 2}$ & & \\
\hline Standar Deviasi & & $\mathbf{5 5 , 2 3 8}$ & \\
\hline
\end{tabular}

\section{Hasil Perhitungan dengan Metode Log Pearson III}

Hasil perhitungan curah hujan rencana dengan menggunakan Metode Log Pearson III dapat diliat pada tabel 2 dibawah ini.

Tabel 3. Perhitungan Metode Log Pearson III untuk Stasiun Meteorologi Maritim Tanjung Priok

\begin{tabular}{ccccc}
\hline Tahun & $\begin{array}{c}\text { Curah Hujan } \\
\text { Maksimum }(\mathrm{Xi})\end{array}$ & $($ Log Xi) & $\begin{array}{c}(\text { Log Xi }- \text { Log } \\
\text { X })^{2}\end{array}$ & $\begin{array}{c}(\text { Log Xi - Log } \\
\text { X) }\end{array}$ \\
\hline $\mathbf{2 0 0 8}$ & 87,9 & 1,94398 & 0,03841 & $-0,00753$ \\
\hline $\mathbf{2 0 0 9}$ & 148,9 & 2,17289 & 0,00108 & 0,00003 \\
\hline $\mathbf{2 0 1 0}$ & 88,3 & 1,94596 & 0,03764 & $-0,00730$ \\
\hline $\mathbf{2 0 1 1}$ & 78,5 & 1,89486 & 0,06008 & $-0,01472$ \\
\hline $\mathbf{2 0 1 2}$ & 75,1 & 1,87563 & 0,06988 & $-0,01847$ \\
\hline $\mathbf{2 0 1 3}$ & 117,8 & 2,07114 & 0,00474 & $-0,00032$ \\
\hline $\mathbf{2 0 1 4}$ & 284 & 2,45331 & 0,09817 & 0,03075 \\
\hline $\mathbf{2 0 1 5}$ & 247 & 2,39269 & 0,06385 & 0,01613 \\
\hline $\mathbf{2 0 1 6}$ & 112,7 & 2,05192 & 0,00775 & $-0,00068$ \\
\hline $\mathbf{2 0 1 7}$ & 148,6 & 2,17201 & 0,00102 & 0,00003 \\
\hline $\mathbf{2 0 1 8}$ & 129,6 & 2,11260 & 0,00075 & $-0,00002$ \\
\hline Jumlah & $\mathbf{1 5 1 8 , 4}$ & $\mathbf{2 3 , 0 8 7 0 6}$ & $\mathbf{0 , 3 8 3 4 2}$ & $\mathbf{- 0 , 0 0 2 1 0}$ \\
\hline Rata-rata & $\mathbf{1 3 8 , 0 3 6 3}$ & $\mathbf{2 , 0 9 8 8 2}$ & $\mathbf{0 , 0 3 4 8 5}$ & $\mathbf{- 0 , 0 0 0 1 9}$ \\
\hline Standar Deviasi & & & $\mathbf{0 , 1 9 5 8 1}$ & \\
\hline
\end{tabular}

\section{Hasil Perhitungan Kebutuhan Air Gedung menurut SNI 03-7065-2005}

Berikut adalah data jumlah penghuni Apartemen Madison Park pada tahun 2019. Data ini akan digunakan untuk menghitung jumlah kebutuhan air gedung menurut SNI 03-7065-2005. Berdasarkan data yang diperoleh, maka jumlah keseluruhan penghuni yang terdaftar di Apartemen Madison Park adalah 669 orang. Menurut SNI 037065-2005, kebutuhan air untuk rumah susun adalah minimal 100 Liter/penghuni/hari. Kebutuhan air pada Apartemen Madison Park adalah 66.900 Liter per hari atau 66,9 $\mathrm{m}^{3}$ per hari, kebutuhan bulanannya adalah $2.007 \mathrm{~m}^{3}$, kebutuhan tahunannya adalah $24.084 \mathrm{~m}^{3}$

\section{Kebutuhan Air Gedung berdasarkan Data Tagihan Air PAM}

Berikut data pemakaian dan tagihan air bulanan Apartemen Madison Park terdapat pada tabel 4 dan tabel 5 dibawah ini.

Tabel 4. Data Pemakaian dan Tagihan Air Apartemen Madison Park Tahun 2017

No. Tahun Bulan Pemakaian $\left(m^{3}\right) \quad$ Tagihan (Rp)




\begin{tabular}{rrcccr}
\hline $\mathbf{1}$ & 2017 & Januari & 1925 & $\mathrm{Rp}$ & $24,062,500$ \\
\hline $\mathbf{2}$ & 2017 & Februari & 2373 & $\mathrm{Rp}$ & $29,662,500$ \\
\hline $\mathbf{3}$ & 2017 & Maret & 2169 & $\mathrm{Rp}$ & $27,112,500$ \\
\hline $\mathbf{4}$ & 2017 & April & 1724 & $\mathrm{Rp}$ & $21,550,000$ \\
\hline $\mathbf{5}$ & 2017 & Mei & 2088 & $\mathrm{Rp}$ & $26,100,000$ \\
\hline $\mathbf{6}$ & 2017 & Juni & 1419 & $\mathrm{Rp}$ & $17,737,500$ \\
\hline $\mathbf{7}$ & 2017 & Juli & 2725 & $\mathrm{Rp}$ & $34,062,500$ \\
\hline $\mathbf{8}$ & 2017 & Agustus & 2114 & $\mathrm{Rp}$ & $26,425,000$ \\
\hline $\mathbf{9}$ & 2017 & September & 2591 & $\mathrm{Rp}$ & $32,387,500$ \\
\hline $\mathbf{1 0}$ & 2017 & Oktober & 2638 & $\mathrm{Rp}$ & $32,975,000$ \\
\hline $\mathbf{1 1}$ & 2017 & November & 2459 & $\mathrm{Rp}$ & $30,737,500$ \\
\hline $\mathbf{1 2}$ & 2017 & December & 2724 & $\mathrm{Rp}$ & $34,050,000$ \\
\hline & & Total & $\mathrm{Rp}$ & $336,862,500$ \\
\hline
\end{tabular}

Tabel 5. Data Pemakaian dan Tagihan Air Apartemen Madison Park Tahun 2018 dan 2019

\begin{tabular}{cccccr}
\hline No. & Tahun & Bulan & Pemakaian $\left(\mathrm{m}^{3}\right)$ & \multicolumn{2}{c}{ Tagihan (Rp) } \\
& & & & \\
\hline $\mathbf{1}$ & 2018 & Januari & 3095 & $\mathrm{Rp}$ & $38,687,500$ \\
\hline $\mathbf{2}$ & 2018 & Februari & 2376 & $\mathrm{Rp}$ & $29,700,000$ \\
\hline $\mathbf{3}$ & 2018 & Maret & 2570 & $\mathrm{Rp}$ & $32,125,000$ \\
\hline $\mathbf{4}$ & 2018 & April & 2098 & $\mathrm{Rp}$ & $26,225,000$ \\
\hline $\mathbf{5}$ & 2018 & Mei & 3728 & $\mathrm{Rp}$ & $46,600,000$ \\
\hline $\mathbf{6}$ & 2018 & Juni & 2828 & $\mathrm{Rp}$ & $35,350,000$ \\
\hline $\mathbf{7}$ & 2018 & Juli & 4156 & $\mathrm{Rp}$ & $51,950,000$ \\
\hline $\mathbf{8}$ & 2018 & Agustus & 4388 & $\mathrm{Rp}$ & $54,850,000$ \\
\hline $\mathbf{9}$ & 2018 & September & 4503 & $\mathrm{Rp}$ & $56,287,500$ \\
\hline $\mathbf{1 0}$ & 2018 & Oktober & 4458 & $\mathrm{Rp}$ & $55,725,000$ \\
\hline $\mathbf{1 1}$ & 2018 & November & 5185 & $\mathrm{Rp}$ & $64,812,500$ \\
\hline $\mathbf{1 2}$ & 2018 & December & 5777 & $\mathrm{Rp}$ & $72,212,500$ \\
\hline $\mathbf{1 3}$ & 2019 & Januari & 5705 & $\mathrm{Rp}$ & $71,312,500$ \\
\hline $\mathbf{1 4}$ & 2019 & Februari & 4606 & $\mathrm{Rp}$ & $57,575,000$ \\
\hline \multicolumn{7}{r}{} & Total & & $\mathrm{Rp}$ & $693,412,500$ \\
\hline
\end{tabular}

\section{Hasil Perhitungan Luas Atap Apartemen Madison Park}

Apartemen Madison Park yang berlokasi di Jalan Letjen S. Parman No. 7. merupakan apartemen yang terdiri dari 2 lobby yaitu lobby Mahogany dan lobby Magnolia. Daerah tangkapan air hujan yang digunakan terdiri dari atap bangunan Apartemen Madison Park yang merupakan dak beton.

Berikut luas daerah tangkapan air hujan Lobby Mahogany

$\begin{array}{lll}\text { - } & \text { Atap I } & : 146 \mathrm{~m}^{2} \\ \text { - } & \text { Atap II } & : 198 \mathrm{~m}^{2} \\ \text { - } & \text { Atap III } & : 185 \mathrm{~m}^{2} \\ \text { - } & \text { Atap IV } & : 367 \mathrm{~m}^{2}+\end{array}$


Total

$$
: \overline{896 \mathrm{~m}^{2}}
$$

Berikut luas daerah tangkapan air hujan Lobby Magnolia

\begin{tabular}{lll} 
- & Atap I & $: 146 \mathrm{~m}^{2}$ \\
- & Atap II & $: 198 \mathrm{~m}^{2}$ \\
- & Atap III & $: 185 \mathrm{~m}^{2}$ \\
- & Atap IV & $: 367 \mathrm{~m}^{2}+$ \\
\hline & Total & $: 896 \mathrm{~m}^{2}$
\end{tabular}

Maka luas total atap adalah $896 \mathrm{~m}^{2}+896 \mathrm{~m}^{2}=1792 \mathrm{~m}^{2}$

\section{Perhitungan Volume Air Hujan yang dapat Ditampung}

Hasil perhitungan jumlah volume air hujan yang dapat ditampung dapaat dilihat pada tabel 6 Tabel 6. Volume Air Hujan yang Dapat Ditampung

\begin{tabular}{|c|c|c|c|c|}
\hline Data & Data Hujan & Periode(tahun) & $\begin{array}{l}\text { Curah Hujan } \\
\text { (mm) }\end{array}$ & $\begin{array}{c}\text { Jumlah Air yang } \\
\text { dapat ditampung } \\
\left(\mathrm{m}^{3}\right)\end{array}$ \\
\hline \multirow{3}{*}{ Curah Hujan Rencana } & \multirow{3}{*}{$\begin{array}{c}\text { Stasiun } \\
\text { Meteorologi } \\
\text { Kemayoran }\end{array}$} & 2 & 141,848 & 254,191 \\
\hline & & 5 & 190,688 & 341,712 \\
\hline & & 10 & 223,025 & 399,660 \\
\hline \multirow{3}{*}{$\begin{array}{c}\text { Curah Hujan Harian } \\
\text { Rata-Rata }\end{array}$} & \multirow{3}{*}{\multicolumn{2}{|c|}{$\begin{array}{l}\text { Stasiun Meteorologi Kemayoran } \\
\text { (139 hari hujan dalam } 1 \text { tahun) }\end{array}$}} & 14,946 & 26,771 \\
\hline & & & $\begin{array}{c}\text { Selama } 1 \\
\text { Bulan }\end{array}$ & 316,794 \\
\hline & & & $\begin{array}{c}\text { Selama } 1 \\
\text { Tahun }\end{array}$ & 3721,169 \\
\hline
\end{tabular}

Contoh perhitungan:

1. Curah Hujan Rencana (Stasiun Meteorologi Kemayoran Periode 2 Tahun)

Jumlah air yang dapat ditampung

$$
\begin{aligned}
& =141,848 \times 1792 \\
& =254191,616 \text { Liter } / 1000 \\
& =254,191 \mathrm{~m}^{3}
\end{aligned}
$$

2. Curah Hujan Harian Rata-Rata (Stasiun Meteorologi Kemayoran)

Jumlah air yang dapat ditampung

(1 hari)

Jumlah air yang dapat ditampung

(1 Bulan)

(1 Tahun)

$$
\begin{aligned}
& =14.9461 \text { x } 1792 \\
& =26771,37959 \text { Liter } / 1000 \\
& =26,771 \mathrm{~m}^{3} \\
& =26771,411 \times 139 / 12 \\
& =316794,658 \text { Liter } / 1000 \\
& =316,794 \mathrm{~m}^{3} \\
& =26.771 \times 139 \\
& =3721,169 \mathrm{~m}^{3}
\end{aligned}
$$

\section{Perhitungan Penampungan Air Hujan}

Hasil perhitungan air hujan yang dapat ditampung terdapat pada tabel 7 dibawah ini. Tabel 7. Volume Air Hujan yang Ditampung Setiap Atap

\begin{tabular}{ccc}
\hline Jenis Atap & $\begin{array}{c}\text { Luas } \\
\left(\mathrm{m}^{2}\right)\end{array}$ & Volume Air yang Ditampung $\left(\mathrm{m}^{3}\right)$ \\
\hline Dak Beton & 1792 & 26,77137959 \\
\hline
\end{tabular}




\section{Perhitungan Penghematan Tagihan Air PAM}

Harga air PAM adalah Rp 12.550,- / $\mathrm{m}^{3}$.

Dari hasil perhitungan jumlah air yang dapat ditampung seperti pada tabel 7, maka didapat penghematan biaya air pada Apartemen Madison Park seperti pada tabel 8 dibawah ini.

Tabel 8. Penghematan Air

\begin{tabular}{|c|c|c|c|c|c|c|}
\hline \multirow[t]{2}{*}{ Data } & \multirow[t]{2}{*}{ Data Hujan } & \multirow{2}{*}{$\begin{array}{l}\text { Periode } \\
\text { (tahun) }\end{array}$} & \multirow{2}{*}{$\begin{array}{l}\text { Curah } \\
\text { Hujan } \\
\text { (mm) }\end{array}$} & \multirow{2}{*}{$\begin{array}{l}\text { Volume Air } \\
\text { Hujan }\left(\mathrm{m}^{3}\right)\end{array}$} & \multicolumn{2}{|c|}{$\begin{array}{l}\text { Penghematan } \\
\text { (Juta Rupiah) }\end{array}$} \\
\hline & & & & & Harian & Tahunan \\
\hline \multirow{3}{*}{$\begin{array}{c}\text { Curah } \\
\text { Hujan } \\
\text { Rencana }\end{array}$} & \multirow{3}{*}{$\begin{array}{l}\text { Stasiun } \\
\text { Meteorologi } \\
\text { Kemayoran }\end{array}$} & 2 & 141,848 & 254,191 & 3,190 & 443,424 \\
\hline & & 5 & 190,688 & 341,712 & 4,288 & 596,099 \\
\hline & & 10 & 223,025 & 399,660 & 5,015 & 697,186 \\
\hline $\begin{array}{l}\text { Curah } \\
\text { Hujan } \\
\text { Harian }\end{array}$ & \multicolumn{2}{|c|}{$\begin{array}{l}\text { Stasiun Meteorologi } \\
\text { Kemayoran (139 hari } \\
\text { hujan dalam } 1 \text { tahun) }\end{array}$} & 14,9461 & 26,771 & 0,334 & 46,700 \\
\hline
\end{tabular}

Perhitungan Penghematan Air Berdasarkan Curah Hujan Rencana Stasiun Meteorologi Kemayoran:

$$
\begin{aligned}
\text { Penghematan Per Hari } & =254191,616 / 1000 \mathrm{~m}^{3} \text { x Rp 12.550,- } \\
& =\mathrm{Rp} 3.190 .104,- \\
\text { Penghematan Per Tahun } & =3190104 \times 139 \\
& =\mathrm{Rp} 443.424 .456,-
\end{aligned}
$$

Perhitungan Penghematan Air Berdasarkan Curah Hujan Harian rata-rata Stasiun Meteorologi Kemayoran:

Penghematan Per Hari = 26,771 $\quad$ Rp 12.550

$=$ Rp 335.976, -

Penghematan Per Tahun $\quad=3721,169 \mathrm{~m}^{3}$ x x Rp 12.550, -

$=$ Rp 46.700.670, -

\section{Perbandingan dengan Kebutuhan Air menurut SNI 03-7065-2005}

Berdasarkan perhitungan menurut SNI 03-7065-2005, kebutuhan air pada Apartemen Madison Park adalah $66,9 \mathrm{~m}^{3}$ per hari, kebutuhan bulanannya adalah $2.007 \mathrm{~m}^{3}$, dan kebutuhan tahunannya adalah $24.084 \mathrm{~m}^{3}$.

\begin{tabular}{lccc}
\hline & \multicolumn{3}{c}{ Pemakaian Air } \\
\cline { 2 - 4 } & \multicolumn{3}{c}{$\begin{array}{c}\text { Realitas } \\
\left(\mathbf{m}^{\mathbf{3}}\right)\end{array}$} \\
\cline { 2 - 4 } & $\mathbf{2 0 1 7}$ & $\mathbf{2 0 1 8}$ & $\begin{array}{c}\text { SNI } \\
\left(\mathbf{m}^{\mathbf{3}}\right)\end{array}$ \\
\hline Harian & 74,85 & 125,45 & 100 \\
\hline Tulan & 2245,75 & 3763,5 & 2.007 \\
\hline
\end{tabular}




\section{Perbandingan dengan Kebutuhan Air menurut Data Tagihan Air}

Berdasarkan perhitungan kebutuhan air menurut data tagihan air, rata-rata pemakaian air per bulan tahun 2017 adalah 2245,75 $\mathrm{m}^{3}$ dan pada tahun 2018 adalah 3763,5 $\mathrm{m}^{3}$ dan rata-rata pemakaian air per hari pada tahun 2017 adalah 74,85 $\mathrm{m}^{3}$ dan pada tahun 2018 125,45 $\mathrm{m}^{3}$.

Maka penghematan air bersih per hari pada tahun 2017 dan 2018 adalah:

Penghematan air tahun 2017

$=26,771 / 74,85 \times 100 \%$

$=35,766 \%$

Penghematan air tahun 2018

$=26,771 / 125,45 \times 100 \%$

$=21,339 \%$

Maka penghematan pengeluaran tahun 2017 dan 2018 dalam persen (\%) adalah:

Penghematan pengeluaran tahun $2017=3721,169 / 26.949 \times 100 \%$

$=13,808 \%$

Penghematan pengeluaran tahun $2018=3721,169 / 45162 \times 100 \%$

$=8,239 \%$

Alternatif lain yang dapat digunakan untuk menghitung penghematan air pada Apartemen Madison Park bila melihat data tahun 2018 curah hujan harian terbanyak yang terjadi pada tahun 2018 adalah 32,753 mm dan jumlah hari hujannya 115 hari

Di peroleh jumlah air yang dapat ditampung

(1 hari)

$=32,753 \times 1792 / 1000$
$=58,693 \mathrm{~m}^{3}$

Jumlah air yang dapat ditampung

(1 Tahun)

$$
\begin{aligned}
& =58,693 \times 115 \\
& =6749,695 \mathrm{~m}^{3}
\end{aligned}
$$

Maka penghematan air bersih per hari pada tahun 2018 adalah:

Penghematan air tahun $2018 \quad=58,693 / 125,45 \times 100 \%$

$=46,7859 \%$

Maka penghematan pengeluaran tahun 2018 dalam persen (\%) adalah:

Penghematan pengeluaran tahun $2018=6749,695 / 45162 \times 100 \%$

\section{KESIMPULAN}

$=14,9455 \%$

\section{Kesimpulan}

Dalam skripsi ini dilakukan analisis untuk mengetahui potensi penghematan air dengan diterapkannya Rainwater Harvesting System. Maka dapat ditarik kesimpulan sebagai berikut:

1. Berdasarkan hasil perhitugan, maka didapat curah hujan harian rata-rata sebesar 14,946 mm pada hari hujan.

2. Berdasarkan perhitungan curah hujan harian rata-rata dan luas area tangkapan sebesar $1792 \mathrm{~m}^{2}$, maka volume air hujan yang dapat ditampung pada 1 hari hujan sebesar $26,771 \mathrm{~m}^{3}$.

3. Berdasarkan kebutuhan air menurut SNI 03-7065-2005, dengan 669 penghuni (2018) didapat kebutuhan air bersih per hari nya sebesar $66,9 \mathrm{~m}^{3}$. Sementara yang tersedia dari hujan rata-rata adalah $26,711 \mathrm{~m}^{3}$ air hujan dalam 1 hari. Maka penerapan Rainwater Harvesting dapat menghemat air sebesar 39,926\% pada hari hujan.

4. Berdasarkan pemakaian air dari data tagihan air tahun 2017 dan 2018, rata-rata pemakaian air per hari pada tahun 2017 adalah 74,85 $\mathrm{m}^{3}$ dan pada tahun 2018 adalah 125,45 $\mathrm{m}^{3}$. Sementara yang tersedia dari data curah hujan harian rata-rata adalah 26,771 $\mathrm{m}^{3}$ air hujan dalam 1 hari. Maka penerapan Rainwater Harvesting dapat menghemat air sebanyak 35,766\% pada hari hujan tahun 2017 dan sebanyak 21,339\% pada hari hujan tahun 2018.

5. Berdasarkan data curah hujan harian rata-rata, dengan volume air hujan yang dapat ditampung per hari sebesar 26,771 $\mathrm{m}^{3}$ dan dengan harga air PAM adalah Rp 12.550,- per $\mathrm{m}^{3}$, maka biaya air yang dapat dihemat per tahun adalah Rp 46.700.670,- dengan perhitungan 139 hari hujan dalam 1 tahun.

\section{Saran}

Berdasarkan hasil analisis, maka disarankan agar dibuat desain lebih rinci beserta perhitungan rencana anggaran biaya (RAB) untuk penerapan Rainwater Harvesting ini di Apartemen Madison Park. Agar hasil lebih akurat, dibutuhkan data curah hujan yang lebih banyak dari pos-pos hujan yang tersebar di sekitar Jabodetabek.

\section{DAFTAR PUSTAKA}

Badan Standardisasi Nasional. 2005. SNI 03-7065-2005: Tata Cara Perencanaan Sistem Plambing 
Data Online Pusat Database - BMKG, (http://dataonline.bmkg.go.id/data_iklim)

Fathi, Ahmad Saiful, et al. 2014. Perancangan Sistem Rain Water Harvesting, Studi Kasus: Hotel Novotel Yogyakarta. Yogyakarta: Teknofisika, Vol.3 No. 2 Edisi Mei 2014, Issn 2089-7154

Google Earth, (https://earth.google.com/web)

Haryono, Yosef. 2016. Buku Kuliah: Drainase. Universitas Tarumanagara.

Maryono, A., dan Santoso, E.N., 2006, "Metode Memanen dan Memanfaatkan Air Hujan Untuk Penyediaan Air Bersih, Mencegah Banjir dan Kekeringan,Kementerian Negara Lingkungan Hidup RI, Jakarta.

UNEP International Technology Centre.2001. Rainwater Harvesting. Murdoch University of Western Australia.

Worm, Janette dan Hattum, Tim Van. (2006), Rainwater Harvesting for Domestic Use, Agromisa Foundation and CTA: Wageningen, The Netherlands 